\title{
Penyelesaian Sengketa Antara Warga Desa Melalui Alternatif Penyelesaian Sengketa Di Luar Pengadilan Di Desa Aikmual
}

\author{
Zunnuraeni *, Galang Asmara, Eduardus Bayo Sili \\ Fakultas Hukum Universitas Mataram
}

\begin{abstract}
Kata Kunci: penyelesaian; sengketa; desa; alternative penyelesaian sengketa di luar pengadilan
\end{abstract}

\begin{abstract}
Abstrak: Berdasarkan otonomi desa, kepala desa serta pemerintahan desa memiliki peranan yang besar dalam rangka mewujukan kemanan dan perdamaian di desa, termasuk melalui penyelsaian sengketa antara warga desa melalui jalur luar pengadilan. Namun demikian banyak pemerintah desa yang belum memahami hal tersebut. Oleh karena itu maka penyuluhan hukum guna memberikan pemahaman mengenai metode penyelesaian sengketa di luar pengadilan. Pengabdian pada masyarakat ini dilakukan dengan tujuan untuk : meningkatkan pengetahuan dan pemahaman khalayak sasaran penyuluhan mengenai metode penyelesaian sengketa di luar pengadilan dan kewenangan desa dalam penyelesaian sengketa di luar pengadilan. Pengabdian di lakukan di desa Aikmual, kecamatan Lombok Tengah dengan kelompok sasaran Kepala desa dan perangkat pemerintah desa, BPD, Kepala dusun serta perwakilan unsur masyarakat. Metode pengabdian dilakuan dengan cara : (1) ceramah, yaitu pemberian materi berkenaan dengan masalah pengabdian; (2) diskusi antara tim penyuluh dengan peserta dan konsultasi hukum.Adapun hasil dari kegiatan pengabdian adalah bahwa : (1) terdapat sejumlah sengketa yang terjadi di masyarakat desa, terutama berkenaan dengan sengketa lahan; (2) bahwa penyelesaian sengketa melalui jalur mediasi telah mulai dilakukan di desa; (3) bahwa adanya keinginan dari warga desa agar adanya program-program penyadaran hukum lebih lanjut di desa.
\end{abstract}

\section{Korespondensi: Zunnuraeni17@unram.ac.id}

\section{PENDAHULUAN}

Pada kehidupan sosial masyarakat, konflik seringkali tidak dapat dihindari. Hal ini tidak lepas dari potensi konflik yang ada pada diri setiap manusia. Dahredorf sebagaimana dikutip oleh Parsudi Suparlan menyebutkan bahwa secara hipotetis potensi-potensi konflik terdapat dalam setiap masyarakat, karena setiap warga masyarakat akan mempunyai kepentingan yang harus dipenuhi, yang dalam pemenuhannya harus mengorbankan kepentingan warga masyarakat lainnya. ${ }^{1}$ Kepentingan-kepentingan tersebut diantaranya adalah berkenaan dengan pemenuhan kebutuhan masyarakat pada bidang ekonomi. Pemenuhan kebutuhan ekonomi merupakan salah satu hal yang mendasar dalam kehidupan manusia. Namun demikian kebutuhan ekonomi bukanlah semata sumber konflik dalam masyarakat, perbedaan pandangan politik, perbedaan nilai-nilai social dan agama juga dapat menjadi sumber konflik dalam masyarakat.

Adapun konflik sosial dapat dimaknai sebagai perselisihan atau pertentangan yang terjadi antar anggota atau masyarakat yang bertujuan mencapai sesuatu yang diinginkan dengan cara saling menantang dengan ancaman kekerasan. ${ }^{2}$ Ancaman kekerasan tersebut dapat

\footnotetext{
${ }^{1}$ Parsudi Suparlan, "Konflik Sosial dan Alternatif Pemecahannya", dalam Antropologi, Vol . 30, No 2, 2006, hlm. 142.

2 Yostam Absalom Yabola, Konflik Sosial, Difahami, Identifikasi Sumbernya dan Dikelola-Kajian Literature, https://www.researchgate.net/publication/322628213 (diakses pada 22 Februari 2019), hlm.
} 
berkembang menjadi sebuah tindakan kekerasan, yang bahkan menjadi sebuah peristiwa kekerasan yang meluas. Tindak kekerasan dapat mengancam stabilitas dan kedamaian dalam kehidupan masyarakat.

Konflik sosial yang berkembang menjadi sebuah peristiwa kekerasan yang meluas dapat berasal dari sebuh permasalahan antar individu atau antar kelompok individu, yang tidak ditangai secara tepat. Hal ini dapat terjadi dalam setiap kelompok masyarakat, termasuk masyarakat di desa. Konflik sosial dalam masyarakat desa yang tidak dikelola dengan baik dapat berakibat pada permasalahan bagi desa secara keseluruhan.

Berdasarkan persfektif hukum, konflik sosial dalam masyarakat dapat berada pada ranah perdata yaitu sengketa-sengketa privat dan konflik sosial yang berada pada ranah pidana yaitu sengketa-sengketa yang berkenaan dengan tindak pidana. Sengketa-sengketa tersebut, baik ranah pidana maupun ranah perdata seringkali diselesaikan melalui penyelesaian sengketa di hadapan pengadilan. Namun demikian, tidak setiap konflik sosial sebaiknya di bawa ke ranah pengadilan, terutama sengketa-sengketa keperdataan. Penyelesaian sengketa bahkan dapat diselesaikan dengan menggunakan hukum ataupun kebijakan-kebijakan yang masih hidup dalam masyarakat.

Penyelesaian sengketa diluar pengadilan atau disebut juga dengan alternatif penyelesaian sengketa di desa telah diatur dalam UU No 6 Tahun 2014 Tentang Desa. Pasal 26 (4) UU No 6 Tahun 2014 Tentang Desa menyebutkan bahwa salah satu kewajiban kepala desa adalah menyelesaikan perselisihan masyarakat di desa. Mengacu pada UU No 6 Tahun 2014 Tentang Desa sebenarnya Kepala Desa mempunyai kewajiban dan kewenangan untuk menyelesaikan persoalan masyarakatnya sehingga seharusnya disini Kepala Desa berfungsi sebagai Mediator Otoriatif untuk membantu menyelesaikan persoalan masyarakat yang ada di desa. $^{3}$

Penyelesaian sengketa dalam masyarakat desa juga dapat diselesaikan berdasarkan hukum adat. Hal ini sebagaimana ditegaskan dalam Pasal 103 (d) UU No 6 Tahun 2014 Tentang Desa yang berbunyi sebagai berikut :

"penyelesaian sengketa adat berdasarkan hukum adat yang berlaku di Desa Adat dalam wilayah yang selaras dengan prinsip hak asasi manusia dengan mengutamakan penyelesaian secara musyawarah;

Sengketa dalam masyarakat di desa bahkan dapat diselenggarakan melalui sidang perdamaian peradilan desa adat. Hal ini sebagaimana ditegaskan dalam Pasal 103 (e) UU No 6 Tahun 2014 Tentang Desa.

Meskipun pemerintah desa memiliki kewenangan untuk menyelesaikan sengketa yang terjadi di antara masyarakat desa, tanpa harus di selesaikan di hadapan pengadilan,namun banyak pemerintah desa yang belum memahami hal tersebut. Oleh karena itu maka perlu di lakukan penyuluhan hukum guna memberikan pemahaman mengenai metode penyelesaian sengketa di luar pengadilan kepada pemerintah desa, pemuka masyarakat, unsur-unsur masyarakat dalam desa serta Badan Perwakilan Desa.

3 Rahmat Muhajir Nugroho, Ilham Yuli Isdiyanto, “ Pelatihan Mediasi ( Alternatif Penyelesaian Sengketa) untuk Kepala Desa dan BPD Se-Kecamatan Imogiri, Kabupaten Bantul”, dalam SNIEMA UAD 2018, hlm. 187. 


\section{METODE}

Penyuluhan hukum dilakukan dengan metode:

1. Ceramah yaitu pemberian materi mengenai diantaranya : (a) Kewenangan Desa dalam Penyelesaian Sengketa di luar Pengadilan; (2) Bentuk-Bentuk Penyelesaian Sengketa di Luar Pengadilan; (3) Nilai-nilai Kearifan Lokal sebagai Dasar Penyelesaian Sengketa di luar pengadilan; dan (4) Penguatan Nilai-Nilai Kearifan Lokal dalam bentuk Peraturan Desa.

2. Diskusi yaitu dengan membuka kesempatan tanya jawab kepada peserta dengan tim penyuluh mengenai materi yang disampaikan. Adanya metode diskusi diharapkan dapat lebih membuka wawasan dan meningkatkan pemahaman peserta penyuluhan mengenai materi yang telah disampaikan oleh tim penyuluh.

3. Konsultasi hukum yaitu dengan memberikan kesempatan kepada peserta untuk mengajukan sejumlah permasalahan hukum berkaitan dengan materi penyuluhan kepada tim penyuluh. Konsultasi hukum dilaksanakan setelah acara penyampaian materi dan diskusi.

\section{PEMBAHASAN}

\section{Tinjauan Umum Penyelesaian Sengketa di Luar Pengadilan}

Sengketa atau masalah hukum antar warga masyarakat dapat berupa sengketa perdata maupun masalah hukum pidana. Sengketa perdata adalah sengketa antara individu berkenaan dengan persoalan-persoalan keperdataan, seperti kewarisan, perjanjian, perceraian serta sengketa hak asuh anak. Sementara masalah hukum pidana antar warga masyarakat dapat timbul manakala terjadi suatu peristiwa hukum pidana yang disebabkan oleh salah satu warga masyarakat. Masalah hukum pidana tersebut diantaranya dapat berupa pencurian, penganiayaan, pencemaran nama baik, kekerasan dalam rumah tangga.

Sengketa atau masalah hukum antar warga masyarakat tersebut dapat diselesaikan melalui jalur litigasi dan jalur non litigasi. Pada jalur litigasi penyelsaian sengketa dilakukan melalui penyelesaian jalur hukum di muka pengadilan. Adapun pada jalur non litigasi penyelesaian sengketa dilakukan di luar pengadilan.

Salah satu metode dalam jalur non litigasi atau penyelesaian sengketa di luar pengadilan adalah mediasi. Secara etimologi, istilah mediasi berasal dari bahasa latin, mediare yang berarti berada di tengah. Makna ini menunjukkan pada peran yang ditampilkan pihak ketiga sebagai mediator dalam menjalankan tugasnya menengahi dan menyelesaikan sengketa antara para pihak. 'Berada di tengah' juga bermakna mediator harus berada pada posisi netral dan tidak memihak dalam menyelesaikan sengketa. ${ }^{4}$

Mediasi merupakan proses negosiasi pemecahan masalah, dimana pihak luar yang tidak memihak (impartial) bekerjasama dengan pihak yang bersengketa untuk mencari kesepakatan bersama. Mediator tidak berwenang untuk memutus sengketa, tetapi hanya membantu para pihak untuk menyelesaikan persoalan-persoalan yang dikuasakan

\footnotetext{
${ }^{4}$ Sebagaimana dikutip dari http://digilib.unila.ac.id/7381/89/BAB\%20II.pdf, hlm. 1, (diakses pada
} 09/09/2019). 
kepadanya. ${ }^{5}$ Definisi yang serupa dituangkan dalam Putusan Mahkamah Agung Nomer 1 Tahun 2016 Tentang Prosedur Mediasi di Pengadilan, yakni sebagai berikut :

"Mediasi adalah cara penyelesaian sengketa melalui proses perundingan untuk memperoleh kesepakatan Para Pihak dengan dibantu oleh Mediator."

Dalam penyelesaian sengketa melalui proses mediasi peran pihak ke -tiga sebagai pihak penengah menjadi sangat penting. Dalam PERMA no 1 Tahun 2016, pihak ke-3 yang membantu para pihak menyelesaikan sengketa disebut sebagai Mediator. Mediator dalam hal ini berperan membantu para pihak mencari berbagai kemungkinan penyelesaian sengketa tanpa menggunakan cara memutus atau memaksakan sebuah penyelesaian. Mediator dalam hal ini harus bersikap netral dan tidak memihak salah satu pihak. Dalam sengketa antar warga masyarakat, maka mediator selayaknya adalah orang-orang yang disegani dan dihormati dalam masyarakat. Adanya charisma tertentu dari tokoh masyarakat yang berperan sebagai mediator diharapkan dapat menekan tingginya intensitas konflik antar warga sehingga warga bersedia untuk duduk bersama dan saling mendengarkan kemauan dari masing-masing pihak.

Pada sengketa antar warga masyarakat di desa, kepala desa dapat menjadi pihak mediator. Kepala desa sebagai kepala pemerintahan di desa yang sejumlah kewenangannya adalah : membina kehidupan masyarakat desa serta membina ketentraman dan ketertiban masyarakat desa. ${ }^{6}$ Lebih tegas tentang peran kepala desa sebagai mediator dalam sengketa antar warga desa dapat merujuk pada ketentuan pasal 26 ayat (4) butir (k) UU No 26 Tahun 2014 tentang Desa.

Adanya peran kepala desa dalam penyelesaian sengketa antar warga di desa diharapkan dapat menghilangkan potensi terjadinya konflik sosial berkelanjutan ataupun terjadinya friksi atau perpecahan dalam masyarakat. Penyelesaian sengketa melalui jalur litigasi yang lebih pada penyelesain win-lose solution tidak jarang menimbulkan perpecahan antara pihak yang bersengketa. Adapun penyelesaian sengketa memalui jalur non litigasi yang berupaya menemukan win-win solution dapat meminimalisir terjadinya friksi atau perpecahan antara pihak yang bersengketa. Hal ini karena para pihak dalam sengketa diberi posisi yang sama, memiliki kesempatan yang sama untuk didengarkan keinginannya karena para pihak dapat sama-sama aktif dalam menentukan penyelesaian sengkata. Akhir dari penyelesaia ini tidak ada yang dikalahkan ataupun dimenangkan, melainkan kesepakatan damai antara para pihak.

Beberapa keuntungan dalam penyelesaian sengketa melalui mediasi adalah sebagai berikut :

1) Mediasi diharapkan dapat menyelesaikan sengketa secara cepat dan relative murah dibandingkan dengan membawa perselisihan tersebut ke pengadilan atau ke lembaga arbitrase.

${ }^{5}$ Khotibul Umam, Penyelesaian Sengketa diluar Pengadilan, Yogyakarta: Penerbit Pustaka Yustisia, 2010, hlm. 10 .

${ }^{6}$ Pasal 26 ayat (2) butir f dan g Undang-Undang Republik Indonesia Nomer 6 tahun 2014 Tentang

Desa. 
2) Mediasi akan memfokuskan perhatian para pihak pada kepentingan mereka secara nyata dan pada kebutuhan emosi atau psikologis mereka, sehingga mediasi bukan hanya tertuju pada hakhak hukumnya.

3) Mediasi memberikan kesempatan para pihak untuk berpartisipasi secara langsung dan secara informal dalam menyelesaikan perselisihan mereka.

4) Mediasi memberikan para pihak kemampuan untuk melakukan control terhadap proses dan hasilnya.

5) Mediasi dapat mengubah hasil, yang dalam litigasi dan arbitrase sulit diprediksi, dengan suatu kepastian melalui suatu konsensus.

6) Mediasi memberikan hasil yang tahan uji dan akan mampu menciptakan saling pengertian yang lebih baik di antara para pihak yang bersengketa karena mereka sendiri yang memutuskannya.

7) Mediasi mampu menghilangkan konflik atau permusuhan yang hamper selalu mengiringi setiap putusan yang bersifat memaksa yang dijatuhkan oleh hakim di pengadilan atau arbiter pada lembaga arbitrase. ${ }^{7}$

\section{Pelaksanaan Kegiatan Pengabdian Pada Masyarakat "Penyelesaian Sengketa Antara Warga Desa Melalui Penyelesaian Sengketa di Luar Pengadilan di desa Aikmual”}

Desa Aikmual berada di dalam wilayah administrasi Kecamatan Praya, Kabupaten Lombok Tengah. Masyarakat pada desa Aikmual berciri homogen, yakni bahwa masyarakatnya pada umumnya berasal dari suku yang sama yaitu suku Sasak, serta agama yang dianut adalah sama yaitu agama islam. Meskipun pada masyarakat homogen potensi konflik lebih kecil dibandingkan pada masyarakat heterogen, namun potensi konflik tetap ada. Oleh karena itu maka peningkatan pemahaman masyarakat desa serta aparatur pemerintahan desa mengenai penyelesaian sengketa di luar pengadilan menjadi sangat penting.

Kegiatan penyuluhan dilakukan dengan pemaparan materi yang dilanjutkan dengan diskusi. Materi yang disampaikan berkenaan dengan perbedaan antara sengketa hukum perdata dan masalah hukum pidana, kewenangan desa berkenaan dengan penyelesaian sengketa antar warga desa, metode penyelesaian sengketa di luar pengadilan. Untuk penguatan pemahaman khlayak sasaran kegiatan pemaparan materi diikuti dengan kegiatan diskusi. Para peserta penyuluhan dapat mengajukan sejumlah permasalahan hukum kepada narasumber (penyuluh). Selain pertanyaan hukum, para peserta penyuluhan juga dapat mengajukan usulan, pendapat maupun pengalaman berkenaan dengan masalah hukum yang menjadi materi penyuluhan. Proses penyampaian materi dan diskusi antara tim penyuluh dan peserta penyuluhan disampaikan dalam gambar berikut :

\footnotetext{
${ }^{7}$ Sebagaimana dikutip dari http://digilib.unila.ac.id/7381/89/BAB\%20II.pdf, hlm. 5, (diakses pada 09/09/2019).
} 


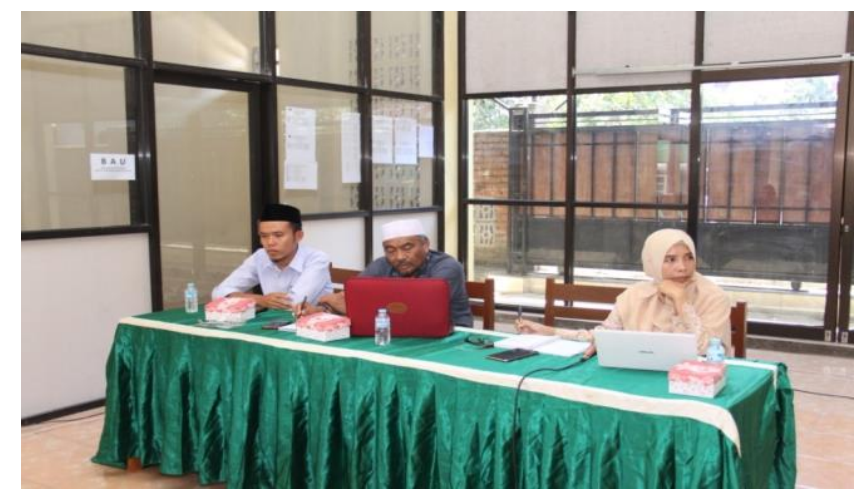

Tim Penvuluh menvampaikan Materi penvuluhan

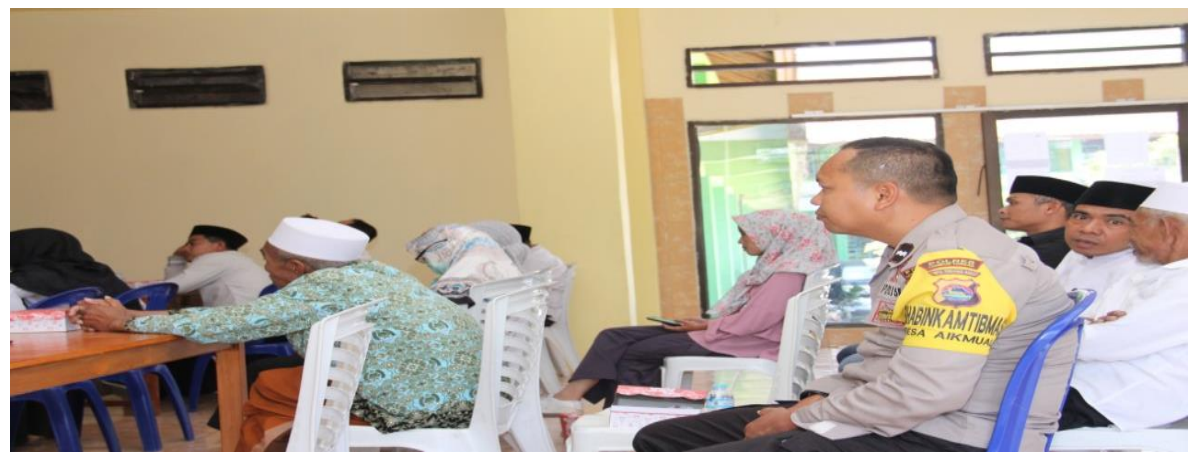

Peserta penyuluhan mendengarkan pemaparan tim penyuluh

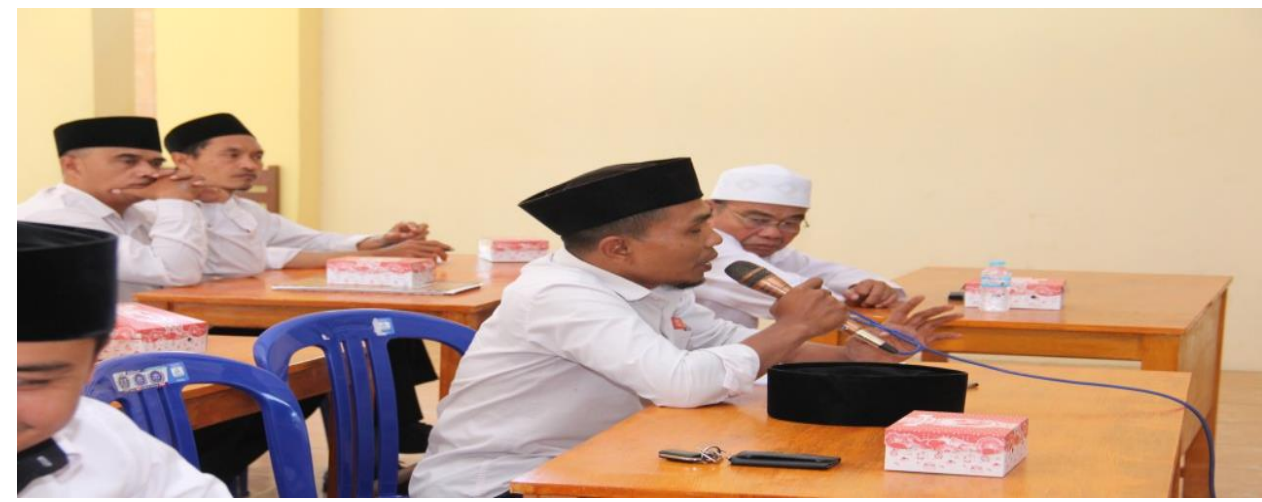

Sesi diskusi : peserta menyampaikan sejumlah permasalahan hukum terkait materi penyuluhan

Secara keseluruhan kegiatan penyuluhan terlaksana dengan baik. Hal ini karena beberapa faktor sebagai berikut :

1. Keterbukaan perangkat pemerintahan desa dalam menerima Tim penyuluh serta mendukung terlaksananya kegiatan diantaranya dengan memfasilitasi penyebaran undangan kepada peserta penyuluhan. 
2. Adanya bantuan dari unsur desa lainnya, yakni dalam hal ini pondok pesantren "Darul Aminin NW Aikmual", dengan menyediakan aula serbaguna madrasah sebagai tempat penyelenggaraan kegiatan penyuluhan.

3. Antusiasme yang cukup tinggi dari peserta penyuluhan dalam mengikuti kegiatan penyuluhan, mulai dari sesi penyampaian materi sampai dengan sesi dialog. Peserta penyuluhan menunjukkan antusiasme dalam mengikuti kegiatan penyuluhan dengan aktif terlibat dalam sesi diskusi. Pada sesi ini peserta mengajukan sejumlah pertanyaan serta berbagi pengalaman berkenaan dengan sengketa yang terjadi di dalam lingkungan masyarakat.

4. Lokasi penyuluhan yang relatif mudah untuk ditempuh dengan kendaraan bermotor dari Kota mataram.

Hasil kegiatan penyuluhan dievaluasi berdasarkan : (1) Tingkat partisipasi khalayak sasaran dalam mengikuti kegiatan penyuluhan' (2) Antusiasme peserta penyuluhan dalam mengikuti kegiatan penyuluhan (3) Masalah-masalah yang disampaikan masyarakat pada sesi diskusi (4) Tingkat pemahaman peserta penyuluhan.

(1) Tingkat Partisipasi Khalayak Sasaran

Tingkat partisipasi khalayah sasaran dalam mengikuti kegiatan tinggi. Hal ini tampak dari terpenuhinya target peserta penyuluhan sebanyak 30 orang.

(2) Antusiasme Peserta Penyuluhan

Anstusiasme peserta penyuluhan cukup tinggi. Hal ini terlihat dari keseriusan peserta dalam mengikuti kegiatan penyuluhan yakni dengan tidak meninggalkan kegiatan mulai dari kegiatan pembukaan hingga kegiatan penutupan. Selain itu juga terlihat dari keaktifan peserta dalam mengajukan berbagai permasalahan hukum pada sesi dialog.

(3) Masalah-masalah yang disampaikan peserta penyuluhan sesuai dengan pertanyaanpertanyaan yang diajukan pada sesi dialog. Sejumlah permasalahan yang diajukan masyarakat pada sesi diskusi adalah :

(a) Penyelesaian sengketa berkenaan dengan tanah. Sengketa tanah adalah salah satu sengketa yang kerap terjadi dalam masyarakat. Sengketa ini dapat berkenaan dengan pembagian warisan, maupun sengketa mengenai pemilik sah atas tanah. Sebagaimana pemaparan dari sekretaris desa, terdapat setidaknya tiga sengketa antara warga berkenaan dengan tanah yang tengah ditangani oleh desa. Selain menekankan pentingnya peran kepala desa dan aparatur maupun pemuka desa dalam menjadi penengah atau mediator bagi sengketa tanah antar warga, tim penyuluh juga mengingatkan warga masyarakat mengenai pentingnya arti dokumen-dokumen resmi, seperti sertifikat hak milik tanah.

(b) Kekuatan hukum putusan mediasi. Pertanyaan lain yang diajukan masyarakat adalah berkenaan dengan kekuatan hukum putusan mediasi. Sekiranya suatu sengketa telah diputus melalui jalur mediasi, namun dikemudian hari salah satu pihak mengingkari putusan mediasi maka bagaimanakah kekuatan sebuah putusan mediasi. Berkenaan dengan kekuatan putusan mediasi, tim penyuluh memaparkan bahwa putusan mediasi harus dituangkan dalam bentuk tertulis dan diajukan 
kepada hakim untuk dikuatkan dalam bentuk akta perdamaian. Sebagaimana ketentuan dalam Pasal 1858 KUHP erdata bahwa perdamaian diantara para pihak mempunyai kekuatan layaknya kekuatan putusan hakim pada tingkat terakhir. Perdamaian tersebut tidak dapat dibantah oleh salah satu pihak dengan alasan kekhilafan mengenai hukum atau alasan bahwa salah satu pihak dirugikan. Berdasarkan Pasal 130 HIR bahwa perdamaian antara para pihak yang telah diajukan pada sidang pengadilan untuk memperoleh akta perdamaian, tidak dapat diajukan banding. Penguatan putusan mediasi melalui akta perdamaian yang diajukan ke hadapan hakim juga ditegaskan dalam PERMA No. 1 tahun 2018.

(c) Pertanyaaan lain yang diajukan tidak berkenaan langsung dengan materi penyuluhan. Masalah hukum yang ditanyakan adalah mengenai kekuatan mengikat awig-awig, khususnya dalam hal ini adalah sanksi awig-awig bagi yang melanggarnya. Awig-awig adalah aturan tentang kehidupan bersama dalam masyarakat yang berasal dari nilai-nilai tradisional yang hidup, tumbuh dan berkembang besama suat masyarakat. Dalam hal ini awig-awig dapat disamakan dengan aturan hukum adat. Pelanggaan terhadap awig-awig dapat menimbulkan sanksi adat. Keberadaan hukum adat dan sanksi adat diakui dan dilindungi keberadaannya berdasarkan Pasal 18 B ayat (2) UUD 1945. Dengan demikian sanksi adat terhadap pelanggaran awig-awig tetap diakui sepanjang dalam kerangka NKRI dan tidak bertentangan dengan hukum nasional.

\section{KESIMPULAN}

Penyuluhan hukum tentang "Penyelesaian Sengketa antar Warga Desa Melalui Alternatif Penyelesaian Sengketa di luar Pengadilan terlaksana dengan baik. Dalam kegiatan penyuluhan ini dua masalah hukum menojol yag diajukan oleh masyarakat adalah sengketa antar warga berkenaan dengan kepemilikan tanah dan kekuatan hukum putusan mediasi.

\section{DAFTAR PUSTAKA}

Khotibul Umam, Penyelesaian Sengketa diluar Pengadilan, Yogyakarta: Penerbit Pustaka Yustisia.

Rahmat Muhajir Nugroho, Ilham Yuli Isdiyanto, “ Pelatihan Mediasi ( Alternatif Penyelesaian Sengketa) untuk Kepala Desa dan BPD Se-Kecamatan Imogiri, Kabupaten Bantul", dalam SNIEMA UAD 2018.

Parsudi Suparlan, "Konflik Sosial dan Alternatif Pemecahannya", dalam Antropologi, Vol. 30, No 2, 2006.

Yostam Absalom Yabola, Konflik Sosial, Difahami, Identifikasi Sumbernya dan DikelolaKajian Literature, https://www.researchgate.net/publication/322628213 (diakses pada 22 Februari 2019)

http://digilib.unila.ac.id/7381/89/BAB\%20II.pdf 